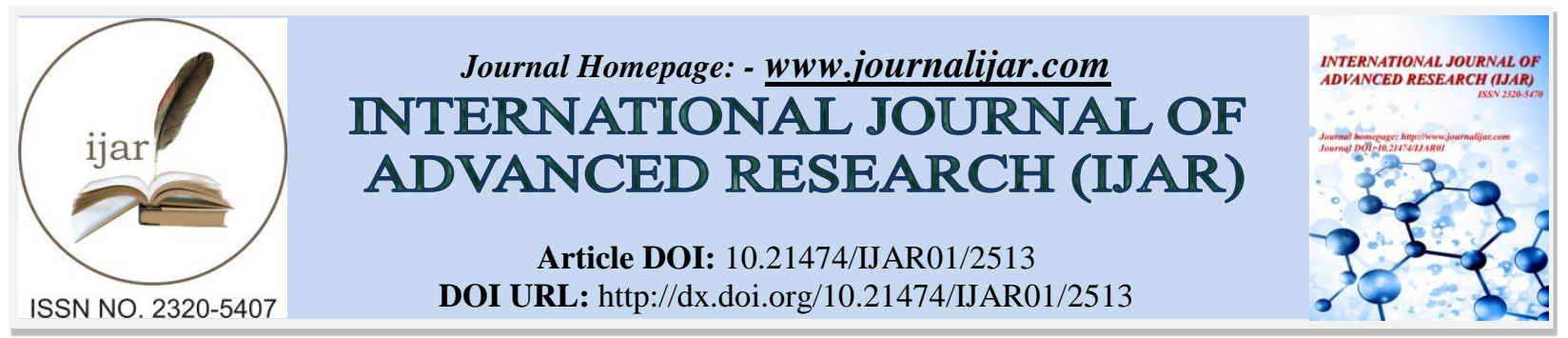

RESEARCH ARTICLE

\title{
BETACYANIN CONTENT AND ANTIOXIDANT ACTIVITY OF SLICE JAM MIXTURE OF KOLANG- KALING (ARENGA PINNATA) AND DRAGON FRUIT PEEL (HYLOCEREUS POLYRHIZUS).
}

Rina Yenrina, Fauzan Azima and Fitria Siti Khumairoh.

Faculty of Agricultural Technology, Andalas University. Padang. West Sumatera 25163. Indonesia.

\section{Manuscript Info}

Manuscript History

Received: 25 October 2016

Final Accepted: 23 November 2016

Published: December 2016

Key words:-

Antioxidant activity, betacyanin, dragon

fruit peel, kolang-kaling

\section{Abstract}

This research aims to determine the mixture effect of dragon fruit peel on characteristics of kolang-kaling slice jam based on chemical properties. This study used a completely randomized design (CRD) with 5 treatments and 3 replications . Data were analyzed by analysis of variance (ANOVA), followed by Duncan's New Multiple Range (DNMRT) at the 5\% significance level. The treatment used is the mixture of kolang-kaling and dragon fruit peel, A (100\%:0\%), B (90\%:10\%), C (80\%:20\%), D (70\%:30\%) and E (60\%:40\%). Based on the research result is known that the mixture of kolang-kaling and dragon fruit peel has significant effect on water content, pectin, betacyanin and antioxidant activity. The result on this research showed that kolang-kaling and dragon fruit peel slice jam at concentration $70 \%: 30 \%$ (treatment D) is the best product with $31,99 \%$ water content; $\mathrm{pH} 3,53$; pectin $2,75 \%$; sucrose $46,11 \%$; betacyanin 5,68mg/100ml; antioxidant activity $30,30 \%$.

Copy Right, IJAR, 2016,. All rights reserved.

\section{Introduction:-}

The development of modern lifestyle has encouraged changing needs of society in terms of both quality and quantity. People are much more wanting everything practically and instantaneous, especially for processed food products such as ready to eat cereals, syrup, jam and powdered drinks. One of processed food products that can be modified to make it more practical presentation that is slice jam.

Slice jam is a modified semi-solid form of jam into a compact slices, plastic and non-sticky. Industries that utilize slice jam biscuits, cakes and other bakery products. The main ingredient in the making of slice jam, ie fruits that are high in pectin and high enough in acid so that jams can form fibers smooth and balance between components of additional in making slice jam such as sugars and acids (Buckle, Edwards, Fleet and Wootton, 1987). Various types of fruit which is often used for making jam slice such as mango, papaya, pineapple and others. So far kolangkaling is not used as a basic ingredient in the making of food products only processed into preserves and compote mixture when kolang-kaling very easy to obtain.

According to Ratima (2014), kolang-kaling contains high nutrient such as phosphorus and calcium. The content of calcium $91 \mathrm{mg}$ in $100 \mathrm{~g}$ of material whereas cow's milk contains $125 \mathrm{mg}$ in $100 \mathrm{~g}$ of whole milk. The high amount of calcium in kaling-kaling can be an alternative source of calcium. Kolang-kaling also contain of fiber ranged from $1.6 \mathrm{~g}$ in $100 \mathrm{~g}$ of material. According to Koiman (1971), the fiber content in kolang kaling a class of carbohydrates in form of galactomannan as hydrocolloid. Galactomannan is a polysaccharide having a sugar 
group, namely galactose and mannose with the percentage of 1: 1.331. Galactomannan with a high content of galactose generally soluble in water and the tendency to form a gel is very low, when compared to galactomannan with low galactose. Percentage of sugar group which is make kolang-kaling has a gel forming properties (Tarigan, 2012). However, the lack of kolang-kaling does not have an attractive color, so it's necessary to add a fruit that has a distinctive color and flavor so that the resulting slice jam more attractive. Therefore, in this study done by mixing red dragon fruit peel.

Red dragon fruit (Hylocereus polyrhizus) contains the nutritional value of a protein, fiber, calcium, phosphorus, iron, vitamin B1, vitamin B2, vitamin B3 and vitamin C (Idawati, 2012). The dragon fruit has peel thickness ranges from $\pm 0.46 \mathrm{~cm}$ with a total peel as much as $21.98 \%$ of the weight of the fruit. However, untapped and simply disposed of as trash when peel dragon fruit has the advantage that the polyphenol content and a good source of antioxidants (Wu, Hsu, Chen, Chiu, Lin and Ho, 2006) and based on research conducted by Jamilah, Kharida, Dzulkifli and Noranizam (2011), dragon fruit peel has a pigment content betacyanin of $150.46 \mathrm{mg} / 100 \mathrm{~g}$. Betacyanin pigment included in betalain group with red-violet color has a function as natural food colorants and can lower cholesterol levels (Wiguna, 2007). Hence, dragon fruit peel is very worthy to be mixture materials in making of slice jam of kolang-kaling because it has criteria that match the attractive colors of the dragon fruit peel.

Based on pre-study obtained that the mixture of kolang-kaling and dragon fruit peel with a of 40:60 and 30:70 obtained slice jam that had a mushy texture. At a ratio of 50:50 texture of slice jam was less compact, but the ratio of 90:10, 80:20, 70:30 and 60:40 the texture was dense and compact. At a ratio of 100: 0 to obtain a very compact texture. From the results of the preliminary pre researchers used ratio of kolang-kaling and peel dragon fruit, namely:100: $0,90: 10,80: 20,70: 30$ and 60:40 for the results obtained near the slice jam. The purpose of this research is to know the effect of mixing dragon fruit peel pulp and kolang-kaling pulp on betacyanin content and antioxidant activity of slice jam produced.

\section{Methodology:-Materials and tools:-}

The materials used in this study was kolang kaling obtained from Pasar Raya Padang, kolang kaling in good quality, has no mucus, dragon fruit peel obtained from the juice seller in Pasar Baru Padang, sucrose (cane sugar), powder jelly Swallow and citric acid. The chemicals used in the analysis include: distilled water, the solution Luff Schrool, $\mathrm{H}_{2} \mathrm{SO}_{4} 6 \mathrm{~N}, 0.1 \mathrm{~N} \mathrm{Na} 2 \mathrm{~S} 2 \mathrm{O} 3$ solution, $1 \mathrm{ml}$ starch indicator, $\mathrm{HCl} 25 \%, 30 \% \mathrm{NaOH}, 1 \%$ acetic acid, $25 \% \mathrm{H}_{2} \mathrm{SO}_{4}$, $\mathrm{NaOH} 1 \mathrm{~N}, \mathrm{KMnO}_{4} 0.01 \mathrm{~N}$, methanol, thio solution, ADS solution, a solution of DPPH.

The equipment used in the manufacture of jam slices include: paper filter, blender, glass baking dish, spoon stainless steel, teflon, stoves, aluminum cup, erlenmeyer, oven, funnel, burette, pipette, $\mathrm{pH}$ meter and so on.

Table 1:- The Formulation of Slice Jam Mixture of Kolang Kaling and Dragon Fruit Peels.

\begin{tabular}{|l|c|c|c|c|c|}
\hline \multicolumn{1}{|c|}{ Ingredients } & \multicolumn{5}{c|}{ Treatments } \\
\hline \multicolumn{1}{|c|}{ Kolang-kaling(g) } & A & B & C & D & E \\
\hline Dragon Fruit Peel(g) & 100 & 90 & 80 & 70 & 60 \\
\hline Jelly powder(g) & \multicolumn{1}{|c|}{0} & 10 & 20 & 30 & 40 \\
\hline Citric acid(g) & 2,5 & 2,5 & 2,5 & 2,5 & 2,5 \\
\hline Sugar(g) & 0,3 & 0,3 & 0,3 & 0,3 & 0,3 \\
\hline
\end{tabular}

Source : Danil (2010) and Putri(2015) with modification

\section{Research Design;-}

The study design used was completely randomized design (CRD) with five treatments and three replications. Observational data were analyzed by analysis of variance (ANOVA) and continued with test of Duncan's New Multiple Range Test (DNMRT) at the 5\% significance level.

In this study, the treatment used was mixing the pulp of kolang-kaling with the red dragon fruit peel pulp against the slice jam. The formulations used based on the formulation made by Danil (2010) and Putri (2015) with modifications as well as by pre-study that has been done. The formulation can be seen in Table 1 .

\section{Observation:-}

For raw material analyzed water content (AOAC, 1995), pH (Yenrina, 2011), pectin content (Gregory,1982), Betacyanins (Eder,1996). For slice jam product analyzed Water content (AOAC,1995), pH (Yenrina, 2011), pectin 
content (Gregory, 1982), sucrose content (Yenrina, 2011), betcyanins content (Eder, 1996), antioxidant activity (Huang, 2005).

\section{Implementation:-}

Making of Kolang Kaling Pulp:-

Kolang kaling washed with clean water and then blended with the addition of water by ratio of kolang-kaling: water (5: $1 \mathrm{w} / \mathrm{v})$, then kolang kaling that has been blended weighed based on treatment (A, B, C, D, and E) ,

Making of Super Red Dragon Fruit Peel Pulp:-(Hylocereus polyrhizus):-

Dragon fruit peel cleaned of its scales and cleaned using water. Then blended in a blender until smooth with a ratio of dragon fruit peel: water $(5: 1 \mathrm{w} / \mathrm{v})$

\section{Making of Slice Jam (modified Roza 2004);-}

Fruit pulp weighed as much as treatments A, B, C, D and E and then put into a container and heated with stirring at a maximum temperature of $40{ }^{\circ} \mathrm{C}-50{ }^{\circ} \mathrm{C}$. Then add $55 \mathrm{~g}$ sugar, $0.3 \mathrm{~g}$ citric acid and gelatin of $2.5 \mathrm{~g}$. Cooking continued until a maximum temperature of $70^{\circ} \mathrm{C}-90^{\circ} \mathrm{C}$ for \pm 30 minutes, continuously stirring during cooking with the stirring condition should not be too fast because it will cause a bubble that could damage the texture and appearance of the final product. Then do "Spoon test" to see formed jam. How do the "Spoon test" which takes a bit of dough with a spoon and then spoon was tilted, if dough immediately fell it mean cooking can be stopped. Cooked jam poured into the pan and leveled to form a slice of $4 \mathrm{~mm}$ and aerated until jam get cold then the jam was cut to adjust the surface of the bread $(8 \times 8 \mathrm{~cm})$.

\section{Results and Discussion:-Analysis of Raw Materials;-}

Analysis of raw material performed on kolang-kaling pulp namely water content, pH, dietary fiber, pectin and calcium. While the analysis performed on dragon fruit peel pulp namely water content, $\mathrm{pH}$, pectin and betacyanin. The results of the analysis of raw materials kolang-kaling and dragon fruit peel can be seen in Table 2.

Table 2:- The Results Of The Analysis Of Raw Materials Kolang Kaling and Dragon Fruit Peel

\begin{tabular}{|l|l|l|}
\hline $\begin{array}{c}\text { Analysis } \\
\begin{array}{c}\text { Water content (\%) pH } \\
\text { Pectin (\%) Betacyanins (mg / 100ml) }\end{array}\end{array}$ & Kolang Kaling & Dragon Fruit Peel \\
\hline
\end{tabular}

Description: (-) do not test

The results of the analysis of water content of dragon fruit peel raw materials around $96.01 \%$ and kolang kaling around $94.85 \%$. The results of this analysis was not much different with Ratima (2014), which stated kolang kaling has a high water content of $94 \%$.

Based on the analysis of kolang kaling acidity obtained around 4.53 and dragon fruit peel acidity around 5.69 . Measurement of $\mathrm{pH}$ on raw materials aim to balance the sugar, acid and pectin during the processing. As stated by Fachruddin (1997), the measurement of $\mathrm{pH}$ is very important because $\mathrm{pH}$ affects the gel formation. Pectin levels in kolang-kaling around $0.93 \%$ and pectin contained in dragon fruit peel around $0.91 \%$. the result of pectin content of the raw material of kolang-kaling was not much different from the results of research conducted by Ulfa (2015), which stated that pectin content in kolang-kaling around $0.95 \%$. Pectin is a matter that affects the formation of the slice jam. As explained by Desrosier (1988), pectin content of $0.5 \%-1.5 \%$ has resulted a pretty well gel. Dragon fruit peel has a betacyanin pigment content of $11.37 \mathrm{mg} / 100 \mathrm{ml}$. Betacyaninis was a source of antioxidants and acts as a natural food colorants (Wiguna, 2007).

\section{Chemical Snalysis:-Water:-}

The results of the analysis of the water content of the slice jam mixture of kolang kaling and dragon fruit peel ranged from $25.91 \%-34,68 \%$. The results of the analysis can be seen in Table 3.

Based on Table 3, known that the mixture of dragon fruit peel had significant effect on the level $(\alpha=5 \%)$ on water content. The highest water level at treatment E was $34.68 \%$ and the lowest water level at treatment $\mathrm{A}$ was $25.91 \%$. This was caused by the mixing of different dragon fruit peel on each treatment. Raw materials in the form of dragon fruit peel has a high water content around $96.01 \%$ so that more dragon fruit peel added, the higher the water content 
of slice jam were obtained. In addition, according to Saneto (2014), dragon fruit peel contained of dietary fiber of 46.7\%. Dietary fiber has a high water absorption due to large polymer size, it has a complex structure and contains many of hydroxyl groups ( Pratiwi, 2011).

Factors that affect the water content of a product can vary depending on component material and fruit were used as the research conducted by Putri (2015), the water content of papaya slice jam around $21.48 \%-34.08 \%$ whereas the research conducted by Ikhwal, Zulkifli and Santosa (2014), the quality of pineapple slice jam had a water content of $14.65 \%-21.68 \%$.

pH:-

$\mathrm{pH}$ measurements are very important because $\mathrm{pH}$ value can affect the gel formation. This is because if the $\mathrm{pH}$ value too high the gel cannot form while the $\mathrm{pH}$ is too low cause syneresis that the water in the gel will be out at room temperature, so that the gel strength will be reduced even the gel cannot totally form (Estiasih and Ahmadi, 2009).

As explained by Desrosier (1988), gel formation occurs in the $\mathrm{pH}$ range from 3.2 to 3.5. Based on the analysis of variance showed that the mixing of dragon fruit peel statistically had not significantly different $(\alpha=5 \%)$ of the $\mathrm{pH}$ value. The lowest $\mathrm{pH}$ value was in treatment $\mathrm{A}$ of 3.483 , while the highest $\mathrm{pH}$ value in treatment $\mathrm{E}$ of 3.558. Slice jam mixture of kolang-kaling and dragon fruit peel has met the criteria expected that is $\mathrm{pH}$ ranged from 3.48 to 3.55 .

Table 3:- Water Content of The Slice Jam Mixture of Kolang Kaling And Dragon Fruit Peel.

\section{Treatments}

A (KK $100 \mathrm{~g}$ : DFP $0 \mathrm{~g})$

B (KK $90 \mathrm{~g}:$ DFP $10 \mathrm{~g})$

C (KK $80 \mathrm{~g}:$ DFP $20 \mathrm{~g})$

D (KK $70 \mathrm{~g}:$ DFP $30 \mathrm{~g})$

E (KK $60 \mathrm{~g}$ : DFP40 g)

\section{Water Content\%}

$25,91 \mathrm{a}$

$26,85 \mathrm{a}$

$29,45 \mathrm{~b}$

$31,99 \mathrm{c}$

$34,68 \mathrm{~d}$

Description: KK = Kolang Kaling, DFP = Dragon Fruit Peel. The number in the same column followed by different lowercase letters are significantly different at level of 5\% Duncan's New Multiple Range Test (DNMRT).

Table 4:- pH of The Slice Jam Mixture of Kolang Kaling And Dragon Fruit Peel

\begin{tabular}{|l|l|}
\hline Treatments & pHValue \\
\hline A $($ KK $100 \mathrm{~g}:$ DFP $0 \mathrm{~g})$ & 3,483 \\
\hline $\mathrm{B}($ KK $90 \mathrm{~g}:$ DFP $10 \mathrm{~g})$ & 3,527 \\
\hline $\mathrm{C}($ KK $80 \mathrm{~g}:$ DFP $20 \mathrm{~g})$ & 3,530 \\
\hline D $($ KK $70 \mathrm{~g}:$ DFP $30 \mathrm{~g})$ & 3,533 \\
\hline E $($ KK $60 \mathrm{~g}:$ DFP $40 \mathrm{~g})$ & 3,558 \\
\hline
\end{tabular}

Description: KK $=$ Kolang Kaling, DFP $=$ Dragon FruitPeel

Table 5:- Pectin Content of The Slice Jam Mixture of Kolang Kaling And Dragon Fruit Peel

\begin{tabular}{|l|l|}
\hline Treatments & Pectin\% \\
\hline A (KK 100 g : DFP 0 g) & $1,42 \mathrm{a}$ \\
\hline B (KK 90 g : DFP10 g) & $2,21 \mathrm{~b}$ \\
\hline C (KK 80 g : DFP 20 g) & $2,33 \mathrm{~b}$ \\
\hline D (KK 70 g : DFP 30 g) & $2,75 \mathrm{c}$ \\
\hline E (KK 60 g : DFP 40 g) & $3,21 \mathrm{c}$ \\
\hline
\end{tabular}

Description: $\mathrm{KK}=$ Kolang Kaling, DFP $=$ Dragon Fruit Peel. The number in the same coulmn followed by different lowercase letters are significantly different at level of 5\% Duncan's New Multiple Range Test (DNMRT). 
Table 6 : - Sucrose Content of The Slice Jam Mixture of Kolang Kaling And Dragon Fruit Peel

\begin{tabular}{|l|l|}
\hline Treatments & SucroseLevel (\%) \\
\hline A (KK $100 \mathrm{~g}:$ DFP 0 g) & 45,49 \\
\hline B (KK 90 g : DFP10 g) & 46,55 \\
\hline C (KK 80 g : DFP 20 g) & 46,54 \\
\hline D (KK 70 g : DFP 30 g) & 46,11 \\
\hline E (KK 60 g : DFP 40 g) & 51,55 \\
\hline
\end{tabular}

Description: KK = Kolang Kaling, DFP = Dragon Fruit Peel

Table 7 : - Betacyanin Content of The Slice Jam Mixture of Kolang Kaling And Dragon Fruit Peel

\begin{tabular}{|l|l|}
\hline Treatments & Betacyaninmg/100ml \\
\hline B (KK $90 \mathrm{~g}:$ DFP $10 \mathrm{~g})$ & $3,01 \mathrm{a}$ \\
\hline C (KK $80 \mathrm{~g}:$ DFP $20 \mathrm{~g})$ & $4,34 \mathrm{~b}$ \\
\hline D (KK 70 g : DFP $30 \mathrm{~g})$ & $5,68 \mathrm{c}$ \\
\hline E (KK 60 g : DFP $40 \mathrm{~g})$ & $6,35 \mathrm{c}$ \\
\hline
\end{tabular}

Description: KK = Kolang Kaling, DFP = Dragon Fruit Peel. The number in the same coulmn followed by different lowercase letters are significantly different at level of 5\% Duncan's New Multiple Range Test (DNMRT).

Table 8:- Antioxidant Activity of The Slice Jam Mixture of Kolang Kaling, And Dragon Fruit Peel

Treatments

A (KK $100 \mathrm{~g}:$ DFP $0 \mathrm{~g})$

B (KK $90 \mathrm{~g}:$ DFP $10 \mathrm{~g})$

C (KK $80 \mathrm{~g}$ : DFP $20 \mathrm{~g})$

D (KK $70 \mathrm{~g}:$ DFP $30 \mathrm{~g})$

E (KK $60 \mathrm{~g}:$ DFP $40 \mathrm{~g})$

Description: $\mathrm{KK}=$ Kolang Kaling, DFP= Dragon Fruit Peel. The number in the same column followed by different lowercase letters are significantly different at level of 5\% Duncan's New Multiple Range Test (DNMRT).

\section{Pectin:-}

Based on the analysis of variance showed that the addition of dragon fruit peel gave significant effect $(\alpha=5 \%)$ on the pectin level obtained. The results of these observations can be seen in Table 5 . Pectin content of slice jam ranged from $1.42 \%-3.21 \%$. The highest value obtained in the treatment $\mathrm{E}$ with an average value of $3.21 \%$ while the lowest value obtained in treatment A with average value of $1.42 \%$. Based on these results mixing dragon fruit peel has an influence on the pectin level of product.

Pectin is a reversible colloid. Pectin is soluble in water, washed, separated, dried and reconstituted without losing the capacity of the gel formation. The role of pectin in gel formation in jam processing greatly affects the texture produced. The density of the fibers that form the jam is determined by the levels of pectin. The higher levels of pectin the more dense the fiber structure. Rigidity of the fiber network is affected by sugar content and acidity. Pectin content of $0.5 \%-1.5 \%$ has produced a gel which is quite good but it depends on the type of the pectin (Desrosier, 1988).

\section{Sucrose:-}

Based on the analysis results obtained sucrose level was ranges from $45.42 \%-51.55 \%$. The results can be seen in Table 6.

The results of the analysis of the sucrose level of the slice jam mixture of kolang-kaling and dragon fruit peel had the highest levels in the treatment $\mathrm{E}$ of $51.55 \%$ while the lowest sucrose level was in treatment $\mathrm{D}$ of $46.11 \%$. The $\mathrm{pH}$ value greatly affect the sucrose content of a food, a food products with high acidity had a $\mathrm{pH}$ value below 3.7 can hydrolyze sucrose into glucose and fructose called invert sugar, so the more sucrose is hydrolyzed, the sucrose concentration is calculated to be less and less (Buckle et al, 1987). As the research that has been conducted by Edward (2014), sucrose level in the soursop extract slice jam ranged from $32.21 \%$ $43.04 \%$ with a $\mathrm{pH}$ of 3.54 to 3.83 . 


\section{Betacyanin:-}

Based on the analysis of variance known that the mixing of dragon fruit peel had significant effect $(\alpha=5 \%)$ on Betacyanin level. The results of these observations can be seen in Table 7.

Based on the analysis of slice jam mixture of kolang-kaling and dragon fruit peel had the highest betacyanin value in treatment $\mathrm{E}$ of $36.35 \mathrm{mg} / 100 \mathrm{ml}$ and the lowest value was in treatment $\mathrm{B}$ of $3.01 \mathrm{mg} / 100 \mathrm{ml}$. On the raw material analysis known that dragon fruit peel had betacyanin pigment of $11.37 \mathrm{mg} / 100 \mathrm{ml}$, but the slice jam had an average value of betacyanin ranged from $3.01 \mathrm{mg} / 100 \mathrm{ml}-6.35 \mathrm{mg} / 100 \mathrm{ml}$ it was due to betacyanin vulnerable to $\mathrm{pH}$. Thus, the content of betacyanin become lower than raw materials dragon fruit peel. As expressed by Fadillah (2014), citric acid can affect the levels of betacyanin of dragon fruit peel. This is because the stability of betacyanin greatly influenced by $\mathrm{pH}$, treatment $\mathrm{A}$ without dragon fruit peel the betacyanin content was not analyzed.

Antioxidant Activity:-

Based on the analysis of variance known that the mixture of dragon fruit peel had significant effect $(\alpha=5 \%)$ on antioxidant activity obtained. The results of these observationscan be

seen in Table 8. From Table 8. known that the antioxidant activity of slice jam was highest in treatment $\mathrm{E}$ of $39.18 \%$. It showed that the higher percentage of antioxidant activity whenthe mixing of dragon fruit peel increased. Table 7. Of betacyanin content showed that the higher the mixing of dragon fruit peel the higher the levels of betacyanin contained on the slice jam so it can affect the antioxidant activity that obtained. Treatment A without mixing of dragon fruit peel has antioxidant activity of $15.10 \%$. As the explanation by Tarigan (2012), stated that galactomannan contained in kolang kaling also has antioxidant properties.

\section{Conclusions and Recomendations:-Conclusion:-}

Based on the research that has been done on slice jam mixture of kolang-kaling and dragon fruit peel concluded as follow:

The result of the analysis were significantly different $(\alpha=5 \%)$ on the water content, pectin, betacyanin levels and antioxidant activity.

\section{Suggestion:-}

Based on research conducted authors suggest for further research to analyze calcium level of slice jam mixture of kolang-kaling and dragon fruit peel, also to analyze its shelf life and choose the type of packaging that can improve its safety.

\section{References:-}

1. [AOAC]. 1995. Official Method of Analysis Association of Analytical Chemist. Washington DC. USA: Assosiatioon Official Analysis Chemist.

2. [BSN] Badan Standarisasi Nasional. SNI 01-3746-2008. Selai Buah: Badan Standarisasi Nasional Indonesia. Jakarta.

3. Buckle, K.A. Edwards. G.H Fleet dan M. Wootton. 1987. Ilmu Pangan. Penerjemah: H. Purnomo dan Adiono. Edisi II. University of Indonesia. Jakarta

4. Danil. 2010. Pembuatan Selai Lembaran dari Campuran Pepaya (Carica Papaya L.) dan Jonjot Labu Kuning (Cucurbitamoschata). Fakultas Teknologi Pertanian Universitas Andalas. Padang

5. Desrosier, N.W. 1988. Teknologi Pengawetan Pangan. UI. Jakarta.

6. Eder, R. 1996. Handbook of Food Analysis, Vol. I. Marcel Dekker Inc. New York.

7. Edwar, H. 2014. Pengaruh Penambahan Sari Daun Sirsak Terhadap Karakteristik Selai Lembaran Buah Sirsak (Annonamuricata, L.).Fakultas Teknologi Pertanian Universitas Andalas. Padang

8. Estiasih,Tand K.Ahmadi. 2009. Teknologi Pengolahan Pangan. PT Bumi Aksara. Jakarta.

9. Fadillah, A. 2014. Penambahan asam sitrat pada penambahan velva. Fakultas Teknologi Pertanian Universitas Andalas. Padang

10. Facruddin,L. 1997. Membuat Aneka Selai. Kanisius. Yogyakarta

11. Gregory, D. J. H. (1982). The Versality of Pectin. in Food Product Industry. [Online], http://jn.nutrition.org/abstrak/. pdf [22 Februari 2016]. 
12. Huang, Yu-Ching, Yung-Ho and Shao, Yi-Yuan. 2005. Effect of Genotype and Treatment on the Antioxidant Activity of Sweet Potato in Taiwan. Food Chemistry 98 (2006) 529-538

13. Idawati, N. 2012. Budidaya Buah Naga Hitam Varietas Baru yang Kian Diburu. Pustaka Baru Press. Jogyakarta

14. Ikhwal., Zulkifli. And Santosa. 2014. Pengaruh Kosentrasi Pektin dan Lama Penyimpanan Terhadap Mutu Selai Nanas Lembaran. Medan. Teknologi Pangan Fakultas Pertanian. Jurnal Rekayasa Pangan dan Pertanian.Vol.2(4):61-70.

15. Jamilah, B, S.,C.E., M, Kharida, M.A. Dzulkifli and A. Noranizam. 2011. Physico-Chemical Characteristics Of Red Dragon Fruit (Hylocereus Polyrhizus). International Food Research Journal 1 (8):279-286.

16. Koiman, P., 1971. Structures of The Galactomannan Seeds of Annonamuricata, Arenga saccharifera, Cocos nucifera, Convolvulus tricolor, and Sophorajaponica, Carbohyd. Res.,20:329- 337.

17. Putri, RS. 2015. Penambahan Tepung Rebung dalam Pembuatan Selai Lembaran Pepaya (Carica papaya L) Fakultas Teknologi Pertanian Universitas Andalas Padang.

18. Pratiwi, M. 2011. Pengaruh Jenis Sumber Serat dan Perbandingan Penstabil Terhadap Mutu Minuman Serat Alami. Fakultas Pertanian.Universitas Sumatera Utara

19. Ratima, S/BPTP. 2014. Khasiat Tersembunyi Kolang-Kaling. Tabloid Sinar Tani. Jawa Barat. http:www.Tabloid Sinar Tani.com/content/read/khasiat tersembunyi kolang-kaling [5Januari2016].

20. Roza, L. 2004.Tingkat Perbandingan Campuran Daging Buah Belimbing Manis Dan Pepaya Terhadap Mutu Selai Lembaran. Fakultas Pertanian Universitas Andalas. Padang

21. Saneto, B. 2014. Karakterisasi Kulit Buah Naga Merah (Hylocereus polyrhizus). Jurnal AGRIKA.Vol2 (2) Hal:143-149

22. Tarigan, BR. 2012. Karakteristik Edible Film bersifat Antioksidan dan Antimikroba dari Galactomannan Biji Aren (Arenga Pinnata) yang di inkorporasi dengan minyak Atsiri Daun Kemangi. [Disertasi]. Fakultas Matematika dan Ilmu Pengetahuan Alam. USU. Medan

23. Ulfa, P. 2015. Pemanfaatan Kolang-kaling (Arenga pinnata ,Merr) Sebagai Bahan Substitusi Rumput Laut (Eucheuma cottonii) dalam Pembuatan Serbuk Agar-agar Fakultas Pertanian.Universitas Andalas. Padang

24. Wiguna,I. 2007. Buah Lezat Berkhasiat Obat. Trubus. Jakarta

25. Wu,L.C.,Hsu,H.W., Chen, Y.C.,Chiu, C.C.,Lin,Y.I. and Ho.J.A. 2006. Antioxidant and Antiproliferative activities of red pitaya. Food Chemistry 95:319-327

26. Yenrina, R. Yuliana and D. Rasjmida. 2011. Metode Analisis Bahan Pangan. Unand Press. Padang 